\title{
PENERAPAN MODEL PEMBELAJARAN PROBLEM SOLVING TERHADAP KEMAMPUAN PEMAHAMAN KONSEP MATEMATIS SISWA
}

\author{
Ramadhani Fitri ${ }^{1}$, Sari Andini² \\ ${ }^{1}$ Dosen Program Studi Matematika STKIP Insan Madani Airmolek \\ ${ }^{2}$ Mahasiswa Program Studi Matematika STKIP Insan Madani Airmolek \\ Ramadhani_fitri44@yahoo.co.id ${ }^{1}$,Sariandini58@yahoo.com ${ }^{2}$
}

\begin{abstract}
This research was conducted based on the lowed capacity draf knowled matematic the student in junior high school one Pasir Penyu. The purpose this research was to obtain draf knowled matematic the student of useing learning model problem solving. The research desain of use randomied subjects Posttest Only Control Group Desin. Data analisis technique in testing used t-tes. The results of analysis was gotteh thet $t_{\text {count }}=2,950$ and $t_{\text {table }}=2,0003$. So the conclusied is "The capacity draf knowled matematic the student with of using learning model problem solving be better. From of The capacity draf knowled matematic the student. With of using knvensional at class VIII junior High School One Pasir Penyu.
\end{abstract}

Keywords: problem solving, understanding of mathematical concept

\begin{abstract}
Abstrak. Penelitian ini dilatarbelakangi oleh rendahnya kemampuan pemahaman konsep matematis siswa Sekolah Menengah Pertama Negeri 1 Pasir Penyu. Tujuan penelitian ini untuk mengetahui kemampuan pemahaman konsep matematis siswa dengan menggunakan model pembelajaran problem solving. Rancangan penelitian yang digunakan adalah Randomized Subjects Posttest Only Control Group Design. Teknik analisis data dalam pengujian menggunakan uji-t. Dari analisis data diperoleh $t_{\text {hitung }}=$ 2,950 dan $\mathrm{t}_{\text {tabel }}=2,0003$. Jadi, dapat diambil kesimpulan kemampuan pemahaman konsep matematis siswa dengan menggunakan model pembelajaran problem solving lebih baik dari pada kemampuan pemahaman konsep matematis siswa dengan menggunakan pembelajaran konvensional dikelas VIII Sekolah Menengah Pertama Negeri 1 Pasir Penyu.
\end{abstract}

Kata Kunci: problem solving, pemahaman konsep matematika

\section{PENDAHULUAN}

Matematika merupakan suatu ilmu yang mempelajari cara berfikir dalam memberikan strategi untuk mengatur, menganalisis, dan mensintesis data atau semua yang ditemui dalam masalah sehari-hari. Melalui pembelajaran matematika siswa diharapkan memiliki kecakapan untuk mengeksplorasi, memprediksi, berfikir rasional dan memecahkan masalah (Suderajat, 2004:43).

Pelajaran matematika disekolah bertujuan untuk membuat siswa belajar mengamati suatu masalah, menganalisis masalah, memahami konsep, memecahkan masalah dan mengambil kesimpulan dari masalah yang ia pecahkan. Hal ini didukung oleh tujuan pembelajaran matematika menurut Standar Isi (SI) yaitu (1) Memahami konsep matematika, menjelaskan keterkaitan antar konsep dan mengaplikasikan konsep atau algoritma, secara luwes, akurat, efisien, dan tepat dalam pemecahan masalah. (2) Menggunakan penalaran pada pola dan sifat, melakukan manipulasi matematika dalam membuat generalisasi, menyusun bukti, atau menjelaskan gagasan dan pernyataan matematika. (3) Memecahkan masalah yang meliputi kemampuan memahami masalah, merancang model matematika, menyelesaikan model, dan menafsirkan solusi yang diperoleh. (4) Mengkomunikasikan gagasan dengan simbol, tabel, diagram, atau media lain untuk memperjelas keadaan atau masalah. (5) Memiliki 
sikap menghargai kegunaan matematika dalam kehidupan, yaitu memiliki rasa ingin tahu, perhatian, dan minat dalam mempelajari matematika, serta sikap ulet dan percaya diri dalam pemecahan masalah (Sri Wardhani 2008:2). Dari kutipan tersebut, maka salah satu tujuan terpenting dalam pembelajaran matematika yaitu memahami konsep matematika karena memahami konsep matematika merupakan kunci utama untuk menyelesaikan permasalahan matematika.

Berdasarkan hasil observasi dan wawancara yang dilakukan oleh peneliti terhadap guru dan siswa kelas VIII di Sekolah Menengah Pertama Negeri 1 Pasir Penyu, peneliti melihat bahwa kemampuan pemahaman konsep matematis siswa masih tergolong rendah. Hal ini dapat dilihat dari cara penyelesaian siswa dalam menjawab soal pada gambar sebagai berikut:

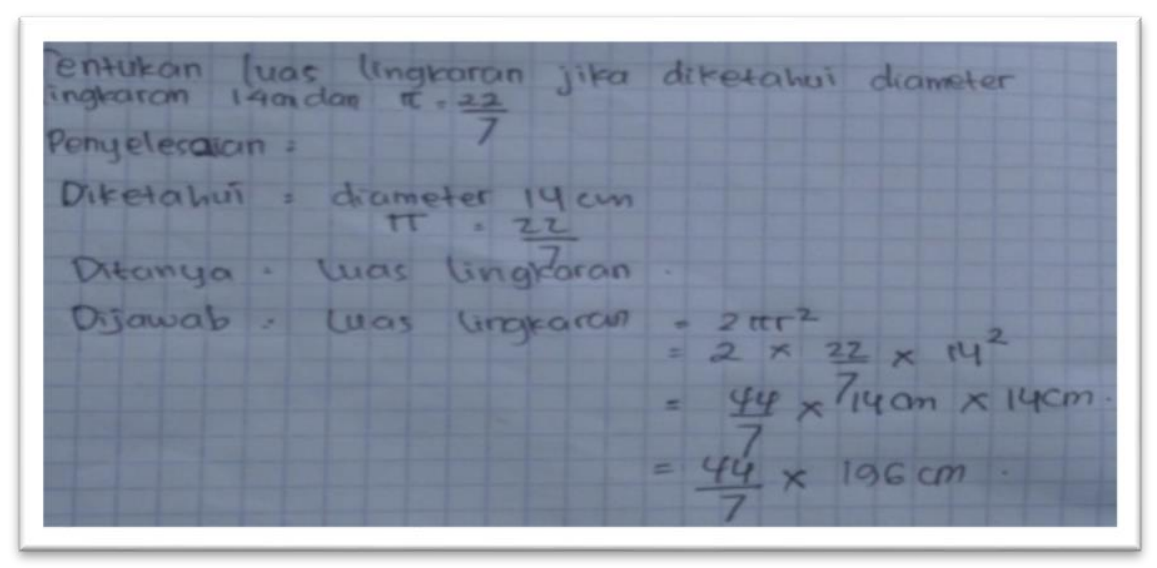

Gambar 1. Pola Penyelesaian Jawaban Siswa pada Tes Kemampuan Pemahaman Konsep Matematis

Dari gambar diatas terlihat bahwa jawaban yang diberikan oleh salah satu siswa tersebut menunjukan bahwa siswa belum mampu memahami konsep dari luas lingkaran, selain itu siswa kurang memahami keterangan yang dibutuhkan untuk menyelesaikan soal tersebut. Dari 30 orang siswa terdapat 10 orang siswa (33\%) yang menjawab benar, 15 orang siswa (50\%) yang menjawab tapi salah, dan 5 orang siswa (17\%) yang tidak menjawab sama sekali. Hal ini menunjukan bahwa kemampuan pemahaman konsep siswa masih tergolong rendah.

Kemudian peneliti melihat pada proses pembelajaran matematika siswa masih enggan bertanya tentang kesulitan yang ia hadapi. Selain itu, ketika siswa ditanya guru tentang kesulitan mereka, siswa tidak memberi respon. Akibatnya siswa tidak mampu menyelesaikan tugas atau latihan yang diberikan guru. Masalah lain yang ditemukan, ketika siswa diberi permasalahan mengenai pembelajaran matematika siswa cenderung menunggu jawaban dari temannya. Dalam pembelajaran matematika siswa kurang dilibatkan sehingga siswa kurang aktif dalam belajar. Keadaan ini mengakibatkan hasil belajar siswa rendah.

Salah satu alternatif pembelajaran yang dapat mengembangkan kemampuan pemahaman konsep matematika adalah dengan menggunakan model pembelajaran problem solving (pemecahan masalah). Model pembelajaran problem solving merupakan pembelajaran aktif, dimana siswa mencari unsur yang diketahui, menemukan cara untuk penyelesaian, membuat kesimpulan dan menguji kebenaran dari hasil yang mereka dapat. Sehingga siswa mampu mengingat, memahami konsep dari matematika. Hal ini sependapat dengan Aris Soimin yang menyatakan bahwa 
problem solving (pemecahan masalah) merupakan suatu keterampilan yang meliputi kemampuan untuk mencari informasi, menganalisis situasi, dan mengidentifikasi masalah dengan tujuan untuk menghasilkan alternatif sehingga dapat untuk mengambil tindakan suatu keputusan untuk mencapai sasaran. Selain itu pendapat ini diperkuat dengan pendapat Polya yaitu pemecahan masalah memuat empat fase penyelesaian, yaitu memahamai masalah, merencanakan penyelesaian, menyelesaikan masalah sesuai rencana, dan melakukan pengecekan kembali terhadap semua langkah yang telah dikerjakan (Suherman, 2003:91).

Pemahaman konsep matematika merupakan landasan penting berpikir dalam menyelesaikan permasalahan matematika maupun permasalahan sehari-hari. Pada peraturan didepdiknas nomor 506/C/kep/PP/2004 tanggal 11 November 2004 tentang rapor pernah diuraikan bahwa indikator siswa memahami konsep matematika adalah (1) Menyatakan ulang sebuah konsep. (2) Mengklasifkasi objek-objek menurut sifatsifat tertentu sesuai dengan konsepnya. (3) Memberi contoh dan bukan contoh dari suatu konsep. (4) Menyajikan konsep dalam berbagai bentuk representasi matematis. (5) Mengembangkan syarat perlu atau syarat cukup dari suatu konsep. (6) Menggunakan dan memanfaatkan serta memilih prosedur atau operasi tertentu. (7) Mengaplikasikan konsep atau algoritma pemecahan masalah (Sri Wardhani 2008: 9).

\section{METODE}

Jenis penelitian ini adalah penelitian eksperimen. Desain penelitian yang digunakan adalah Quasi Experimental Design dengan bentuk Randomized Subjects Posstest Only Control Group Design (Setyo, 2013: 44).

Tabel 1. Desain Penelitian

\begin{tabular}{llcc}
\hline & Group & Variabel terikat & Postes \\
\hline $\mathrm{R}$ & Eksperimen & $\mathrm{X}$ & $\mathrm{Y}_{2}$ \\
\hline $\mathrm{R}$ & Kontrol & & $\mathrm{Y}_{2}$ \\
\hline
\end{tabular}

Keterangan:

$\mathrm{R}=$ Randomisasi

$\mathrm{X}=$ Perlakuan

$\mathrm{Y}_{2}=$ Posttest

Populasi dalam penelitian ini berjumlah 225 dengan jumlah kelas sebanyak 7 kelas, karena terdapat dua kelas unggul pada populasi. Kedua kelas ini tidak diikut sertakan dalam pengambilan sampel. Pengambilan sampel dilakukan secara random dengan jenis Cluster Random Sampling. Sampel yang dibutuhkan yaitu dua kelas. Tahap pengambilan sampel terlebih dahulu menguji normalitas data. Dari hasil uji normalitas populasi diperoleh nilai signifikan signifikan pada kelas $\mathrm{VIII}^{3}$, VIII ${ }^{6}$ dan VIII $^{7}$ lebih besar dari $\alpha=0,05$ maka, dapat disimpulkan bahwa kelima kelas tersebut berdistribusi normal. Sedangkan nilai signifikan kelas VIII ${ }^{4}$ dan kelas VIII ${ }^{5}$ kecil dari pada $\alpha=0,05$ sehingga, kedua kelas tersebut tidak berdistribusi normal. Untuk selanjutnya pengujian kesamaan rata-rata menggunakan uji Kruskal-Wallis karena data ada yang tidak berdistribusi normal (Rostina Sundayana 2010:87). Hasil uji Kruskal-Wallis nilai signifikan yang diperoleh adalah 0,180 . Sehingga nilai signifikan 
lebih besar dari pada 0,05. Maka, dapat simpulkan populasi memiliki kesamaan ratarata untuk taraf nyata $\alpha=0,05$. Setelah pengujian dilakukan sampel dipilih secara acak didapat kelas eksperimen adalah kelas VIII ${ }^{7}$ dan kelas kontrol adalah kelas VIII ${ }^{6}$.

Instrumen yang digunakan dalam penelitian ini menggunakan metode tes yang jenisnya berupa uraian. Teknik analisa data yang digunakan yaitu dengan menggunakan uji " $t$ " (Independent Sample T-Test). Uji ini dilakukan karena data kedua kelas sampel berdistribusi normal dan homogen.

\section{HASIL DAN PEMBAHASAN}

Penelitian yang telah dilaksanakan dengan judul "Penerapan Model Pembelajaran Problem solving Terhadap Kemampuan Pemahaman Konsep Matematis Siswa Kelas VIII Sekolah Menengah Pertama Negeri 1 Pasir Penyu". Populasi dalam penelitian ini adalah kelas VIII, sampel yang diambil adalah kelas VIII ${ }^{6}$ sebagai kelas eksperimen dan VIII $^{7}$ sebagai kelas kontrol. Kelas eksperimen diberi perlakuan dan kelas kontrol tidak diberi perlakuan. Dari hasil pengolahan data untuk masing-masing kelas diperoleh nilai rata-rata dan simpangan baku dengan menggunakan bantuan SPSS 16.0 for Windows seperti terdapat pada tabel:

Tabel 2. Deskripsi Hasil Tes Kemampuan Pemahaman Konsep Matematis Siswa

\begin{tabular}{lccccc}
\hline \multicolumn{1}{c}{ Kelas } & $\mathbf{N}$ & $\boldsymbol{\Sigma}$ & $\widetilde{\boldsymbol{x}}$ & $\mathbf{S}$ & $\mathbf{s}^{\mathbf{2}}$ \\
\hline Eksperimen & 32 & 2551 & 79.718 & 12.82 & 164.27 \\
\hline Kontrol & 32 & 2222 & 69.437 & 14.98 & 224.38 \\
\hline
\end{tabular}

Teknik analisis data dalam penelitian ini dilakukan untuk menguji hipotesis dengan menggunakan langkah-langkah sebagai berikut: a) Uji Normalitas Data. Berdasarkan uji normalitas kelas sampel hasil yang didapat nilai signifikan sebesar 0,214 dengan nilai $\alpha(0,05)$. Karena signifikan lebih besar dari $\alpha=0,05$ maka dapat disimpulkan bahwa kedua sampel berdistribusi normal. b). Homogenitas Data. Dalam normalitas diketahui bahwa sampel berasal dari populasi yang berdistribusi normal, langkah selanjutnya adalah melakukan uji homogenitas menggunakan uji $F$ dengan bantuan program SPSS 16.0 for Windows dengan taraf signifikansi 0,05. Berdasarkan hasil perhitungan uji homogenitas, bahwa signifikan yang diperoleh adalah 0,213 dan $\alpha=0,05$. Karena signifikan $>\alpha$ maka dapat disimpulkan kedua kelas sampel mempunyaivariansi yang homongenitas.

Selanjutnya melakukan uji hipotesis dengan uji t. Berdasarkan hasil uji hipotesis menggunakan $U j i-t$ diperoleh nilai $t_{\text {hitung }}=2,950$ dan $t_{\text {tabel }}=2,0003$ dengan taraf nyata ( $\alpha$ ) 0,05. Karena nilai thitung $>t_{\text {tabe }}$ ini berarti bahwa $H_{0}$ ditolak dan $H_{a}$ diterima, artinya hipotesis diterima yaitu "kemampuan pemahaman konsep matematis siswa dengan menggunakan model pembelajaran problem solving (pemecahan masalah) lebih baik dari pada kemampuan pemahaman konsep matematis siswa dengan menggunakan pembelajaran konvensional di kelas VIII Sekolah Menengah Pertama Negeri 1 Pasir Penyu".

\section{KESIMPULAN DAN SARAN}

Kesimpulan dari penelitian ini adalah kemampuan pemahaman konsep matematis siswa dengan menggunakan model pembelajaran problem solving (pemecahan masalah) lebih baik dari pada kemampuan pemahaman konsep matematis 
siswa dengan menggunakan pembelajaran konvensional dikelas VIII Sekolah Menengah Pertama Negeri 1 Pasir Penyu.

Adapun saran dari peneliti yaitu diharapkan pada guru-guru matematika agar dapat menggunakan model pembelajaran problem solving, karena model pembelajaran ini dapat meningkatkan hasil pemahaman konsep matematis siswa. Bagi penelitipeneliti berikutnya yang tertarik dengan model pembelajaran problem solving dapat memperhatikan manajemen waktu pelaksanaan pembelajaran dan manajemen kelompok. Diharapkan kepada guru bidang studi selain dari matematika agar dapat menggunakan model pembelajaran problem solving pada pembelajaran, karena model pembelajaran ini menuntut agar siswa dapat mengetahui langkah-langkah untuk menyelesaikan suatu masalah.

\section{DAFTAR PUSTAKA}

Setyo, Punaji. 2013. Metde Penelitian Pendidikan \& Pengembangan, (Jakarta: Kencana Pranada Media Group, Cetakan ke-3)

Suherman, H Erman, dkk. 2003. Strategi Pembelajaran Matematika Kontenporer (Bandung: Universitas Pendidikan Indonesia).

Shoimin, Aris. 2014. 68 Model Pembelajaran Inovatif dalam Kurikulum 2013, (Jakarta:Ar-ruzz Media).

Suderajat, Hari. 2004. Implementasi Kurikulum Berbasis Kompetensi (KBK), (Bandung: CV Cipta Cekas Grafika)

Sundayana, Rostina. 2010. Statistika Penelitian Pendidikan (Garut: STKIP Garut, Cetakan Pertama)

Wardhani, Sri. 2008. Analisis SI dan SKL Mata Pelajaran Matematika Sekolah Menengah Pertama (SMP)/MTS Untuk Optimalisasi Pencapaian Tujuan, (Yogyakarta: Pusat Pengembangan dan Pemberdayaan Pendidik dan Tenaga Kependidikan). 